Island Studies Journal, Vol. 3, No. 1, 2008, pp. 17-36

\title{
The Challenge of Nissology: A Global Outlook on the World Archipelago Part II: The Global and Scientific Vocation of Nissology
}

\author{
Christian Depraetere \\ Institut de Recherche pour le Développement (IRD formerly ORSTOM) \\ Montpellier, France \\ christian.depraetere@hmg.inpg.fr
}

\begin{abstract}
Islands are the rule and not the exception. One major objective for nissology - defined as the study of islands and islandness - in the $21^{\text {st }}$ century should be to debunk the unfair prejudice that 'island studies' continues to suffer at present time. To do so, a systematic treatment of the island phenomenon needs to be undertaken and this should be backed up by substantial theoretical underpinnings. In seeking to turn the dominant continental paradigm on its head, islands not only deserve to be "studied on their own terms"; they also become the deus ex machina of a holistic understanding of the world archipelago and its ongoing globalization. This vision should contribute towards bridging the gap between 'continentalists' who tend to consider islands only as epiphenomena of larger land trends, and 'island studies' practitioners. This paper, the second of two segments, focuses mainly on the contribution of islands to global cultural and biological diversity, and concludes with an appeal for a more rigorous, pan-epistemic treatment of island studies.
\end{abstract}

Keywords: nissology, island studies, world archipelago, biodiversity, ethnotope.

(C) 2008 - Institute of Island Studies, University of Prince Edward Island, Canada.

\section{I: Islands as Cultural and Environmental Bellwethers of the $21^{\text {st }}$ Century}

A political leader recently declared that "[i]slands are the bellwethers of international environmental policy" (GLISPA meeting, September 2007). Do they really deserve this flattering epithet? Is this statement also applicable to cultural matters? To answer these questions, one should first consider the resources and specificities of islands in environmental and cultural terms. On one hand, it is generally admitted that islands are major sanctuaries of biodiversity and places where many communities strive to maintain a vibrant cultural identity. On the other hand, many island locales are by definition fragile and marginal due to their geographical nature. They are consequently regarded as vulnerable "hotspots" from both biological and cultural viewpoints. Thus, when the tropical sub-national jurisdictions for which they remain ultimately answerable are taken into account, France and the United Kingdom together share responsibility for the third most numerous compendium of the world's recognized global diversity. Of this total of 1,116 species for which just these two countries are responsible, 824 are listed as threatened (www.biodiplomacy.org, 2007) (See Table 1 and Table 2). 
Table 1: Top 20 Ranking Countries for Threatened Species: Critically Endangered, Endangered and Vulnerable Species (IUCN: after Orr, 2007).

\begin{tabular}{|c|c|c|c|c|c|}
\hline Rank & Country & $\begin{array}{c}\text { Grand } \\
\text { Total }\end{array}$ & $\begin{array}{c}\text { \% } \\
\text { Included }\end{array}$ & $\begin{array}{c}\text { Islands } \\
\text { Sub-total }\end{array}$ \\
\hline $\mathbf{1}$ & Ecuador & 2178 & 8.4 & Galapagos & \\
\hline $\mathbf{2}$ & USA & 1179 & 4.5 & Puerto Rico, Hawaii... & \\
\hline & France+UK & $\mathbf{1 1 1 6}$ & 4.3 & FOT+UKOT & $\mathbf{8 2 4}$ species \\
\hline $\mathbf{3}$ & Malaysia & 911 & 3.5 & North Borneo & \\
\hline $\mathbf{4}$ & Indonesia & 850 & 33 & Wallacea, West NG & \\
\hline $\mathbf{5}$ & Mexico & 840 & 3.2 & few outlying & \\
\hline $\mathbf{6}$ & China & 797 & 3.1 & Hainan & \\
\hline $\mathbf{7}$ & France & $\mathbf{7 4 3}$ & 2.9 & FOT & $\mathbf{5 6 2}$ species \\
\hline $\mathbf{8}$ & Brazil & 725 & 2.8 & & \\
\hline $\mathbf{9}$ & Australia & 623 & 2.4 & many outlying & \\
\hline $\mathbf{1 0}$ & Colombia & 604 & 2.3 & & \\
\hline $\mathbf{1 1}$ & India & 560 & 2.2 & few outlying & \\
\hline $\mathbf{1 2}$ & Madagascar & 542 & 2.1 & Island & \\
\hline $\mathbf{1 3}$ & Tanzania & 539 & 2.1 & many outlying & \\
\hline $\mathbf{1 4}$ & Cameroon & 512 & 2.0 & & \\
\hline $\mathbf{1 5}$ & Peru & 512 & 2.0 & & \\
\hline $\mathbf{1 6}$ & Philippines & 466 & 1.8 & Wallacea & \\
\hline $\mathbf{1 7}$ & Sri Lanka & 457 & 1.8 & Island & \\
\hline $\mathbf{1 8}$ & South-Africa & 396 & 1.5 & Marion \& PE islands & \\
\hline $\mathbf{1 9}$ & U. K. & $\mathbf{3 7 3}$ & 1.4 & UKOT & $\mathbf{2 6 2}$ species \\
\hline $\mathbf{2 0}$ & Panama & 315 & 1.2 & & \\
\hline & World & 27760 & 100.0 & & \\
\hline
\end{tabular}

\section{Islands in the Turmoil of Global Biological and Cultural Diversity}

What is the situation at the international level? Since the $8^{\text {th }}$ Conference of the Parties to the Convention on Biological Diversity (CBD/CoP-8) of March 2006, island biodiversity has become a priority for the United Nations, thanks mainly to the lobbying of island states within that forum (Depraetere \& Dahl, 2007: 101-103). For instance, the "Micronesian Challenge" commits at least $30 \%$ of near shore marine resources and $20 \%$ of forest resources across Micronesia to conservation by the year 2020. The preservation of biodiversity is a corner stone of sustainable development on these and various other islands.

Cultural diversity is the other specific richness of islands. If one takes language as a major criterion of such diversity, then small islands should be considered as key elements for language preservation, and especially so in the Pacific region:

"Language is one manifestation of cultural diversity in small island settings such as the fact that about 1,300 languages and many more dialects are spoken in the Pacific-Oceania region, representing about a fifth of the world's languages, with an average of only 5,000 speakers per language" (Wurm, 2001). 
Table 2: Threatened Species in the FOT and UKOT (Census 2007, IUCN).

\begin{tabular}{|c|c|c|c|c|c|}
\hline $\begin{array}{c}\text { French Overseas Departments and } \\
\text { Territories (FOT) }\end{array}$ & Terrestrial & Aquatic & Other & Plants & Total \\
\hline New Caledonia & 23 & 27 & 1 & 219 & 270 \\
\hline French Polynesia & 36 & 41 & 0 & 47 & 124 \\
\hline French Guiana (not an island) & 19 & 22 & 0 & 16 & 57 \\
\hline Réunion & 13 & 20 & 2 & 16 & 51 \\
\hline Guadeloupe & 16 & 16 & 0 & 8 & 40 \\
\hline Martinique & 11 & 16 & 0 & 9 & 36 \\
\hline French Southern Territories & 15 & 2 & 0 & 0 & 17 \\
\hline Wallis and Futuna & 9 & 3 & 0 & 1 & 13 \\
\hline Mayotte & 7 & 1 & 1 & 0 & 9 \\
\hline St Pierre and Miquelon & 1 & 1 & 0 & 0 & 2 \\
\hline $\begin{array}{c}\text { United Kingdom Overseas Territories } \\
\text { (UKOT) }\end{array}$ & 150 & 149 & 4 & 316 & 619 \\
\hline Saint Helena & 20 & 11 & 2 & 26 & 59 \\
\hline British Virgin Islands & 10 & 14 & 0 & 10 & 34 \\
\hline Pitcairn & 11 & 12 & 0 & 7 & 30 \\
\hline Montserrat & 8 & 15 & 0 & 4 & 27 \\
\hline Falkland Islands & 14 & $\frac{5}{5}$ & 0 & 5 & 24 \\
\hline Cayman Islands & 7 & 15 & 0 & 2 & 24 \\
\hline Anguilla & 5 & 15 & 0 & 3 & 23 \\
\hline Turks and Caicos & 8 & 13 & 0 & 2 & 23 \\
\hline Gibraltar (not an island) & 4 & 11 & 0 & 0 & 15 \\
\hline British Indian Ocean Territory & 2 & 7 & 0 & 1 & 10 \\
\hline South Georgia \& South Sandwich Islands & 8 & 0 & 0 & 0 & 8 \\
\hline UK Overseas Territories (UKOT) & 97 & 118 & 2 & 60 & 277 \\
\hline FOT+UKOT & 247 & 267 & 6 & 376 & 896 \\
\hline FOT+UKOT (islands only) & 224 & 234 & 6 & 360 & 824 \\
\hline France (Mainland) & 27 & 61 & 29 & 7 & 124 \\
\hline UK+Channel Islands+Man (Mainland) & 12 & 24 & 8 & 13 & 57 \\
\hline France+UK (Mainland) & 39 & 85 & 37 & 20 & 181 \\
\hline WORLD & 9,712 & 5,409 & 1,685 & 9,118 & 25,924 \\
\hline
\end{tabular}

In other parts of the world, islands are at the forefront of locations where old languages have been fossilized or at least preserved from many influences. This is the case of the Socotri spoken on the island of Socotra (inhabited since around 1000 BC): an unwritten language of pre-Islamic origin from Southern Arabia. Another example comes from Icelandic, with a grammar comparable to that of Old Norse and which may be considered as a dialect of that medieval language.

But islands are not only an ultimate refuge of shrinking cultures and fossilised languages. Conversely, it is noteworthy that "they have in fact served as great 'crossroads' for human cultural interaction" (Wurm, 2001; UNESCO, 2008) and testify to the mixing of cultures at least through the existence of creoles, pidgins of other cross-breeding languages. Sui generis, the Maltese language is mostly based on Tunisian Arabic, but with strong influences from Sicilian, Italian and English and appears as a bridge between the two shores of the Mediterranean. The Bichlamar spoken in Vanuatu goes along The Tok Pisin 


\section{Depraetere}

("Talk Pidgin") of Papua New-Guinea and the vanishing Rabaul German Pidgin in the Pacific. But the main insular zones where the Creole linguistic melting-pot is encountered are in the Antilles and the South-West Indian Ocean. The best prototype of cross-cutting language is probably the Papiamento spoken in the Dutch Caribbean. This is primarily based on Portuguese or Spanish and to a lesser extent Dutch, African, and Amerindian languages. On the other side of the globe, the "Bourbonnais" creole (from Bourbon, the former name of La Réunion) gave birth to variants of pidgin French in Mauritius, Réunion, Seychelles, Rodrigues and Chagos, giving this group of islands a specific cultural identity.

\section{Global Nissology: Benefits of Insulation in understanding the 'Eco Principle,'}

It is then quite obvious that, despite their differences, biological and cultural processes both benefit from the insulating effects of nature. Islands have to be reckoned with as loci for major issues and developments, also in the $21^{\text {st }}$ century. Accepting this fact would motivate the growth of nissology.

The new paradigm of islands as environmental and cultural bellwethers requires a holistic and normative approach that nissology is hoping to secure. At this stage, it may be convenient to put forward the "eco principle" as developed by Arthur Dahl (1996: 49) and reproduced hereunder:

"With the eco as a unifying concept, we can also redefine ecology as the study or knowledge of the ecos and economics as the management of ecos. Both then take on a larger sense than in their traditional usage, and their complementarities becomes evident ... This unity of word roots also reflects an underlying unity of purpose and function that should link ecology and economy ... The chasm between economics and ecology is a symptom of the malfunctioning of modern society which threatens our very future."

Due to the strong sense of place that they engender, islands are the ideal spaces to experience the pernicious and dysfunctional chasm between these two separate ecos. Islands magnify the schizophrenic practices of these two types of 'development'. More than elsewhere, ecology and economy can be split apart, from individual conceptualization to policy formulation. This can be illustrated by a personal experience in New Caledonia. While I was attending a meeting about coastal zone and coral reef protection on this hotspot of biodiversity, I was stunned that the front page of the only daily newspaper on the island, was boldly advertising the construction of a future new town "with the centre of the city built upon a mangrove" (Depraetere \& David, 2008).

The restricted geographical limits of the island, and its finite resources (including land), render more likely (though not inevitable) a local confrontation with the inconsistency of certain projects. Anthropologist Clyde Kluckhohn (1970: 215) acknowledged this phenomenon thus:

\footnotetext{
1 'Eco' is derived from the Greek oikos, which means home or house.
} 
"Part of our time we are dray horses; the rest of the time we are listless consumers of goods ... Most thoughtful Americans [should not we say "world citizens"] are concerned about the fact that the theory and the practice of our culture are hopelessly out of line. It is well established that while cultural content often changes rapidly, cultural forms often have extraordinary permanency. Thus it is only the "tradition" of economic independence which truly survives. For all our talk of free enterprise, we have created the most vast and crushing monopolies in the world."

The ecological and economic collapse of Nauru (Gowdy \& McDaniel, 1999) illustrates the ultimate consequences of such blindness. The decline of the Easter Island culture even before European arrival is also viewed as an ecological breakdown (Ponting, 1993). Diamond (1995) used Rapa Nui as a parable of the dangers of environmental destruction: "the clearest example of a society that destroyed itself by over exploiting its own resources"

Should the aim of nissology be postulated as that of learning from 'the island effect' for a better understanding of human and nature interactions? Dahl (1996: 47) defined the eco as "any natural or [hu]man-made functional system with internal integrity and distinct features and behaviours enclosed within clear boundaries". The island appears to be the most convenient geographical object with the requirements of such "clear boundaries" and "distinct features and behaviour", including much more internal than external interactions.

\section{II: A Pedagogic and Mnemonic Tool to get to grips with Archipelagic Globalization}

\section{A Modern Periegesis of the Ecumene}

One task of nissology is to develop an understanding of 'the world archipelago'. What, however, results from such an island weltanschauung? In this exercise of re-envisaging the world through island eyes, there is a heightened sense of awareness, of totality:

"[t]hat world history is not just a subject, but a method, and the methodological questions it raises may be resolved best through trans-local approaches to history that are not confined by the boundaries of the spatial units of modernity" (Dirlik, 2005: 397).

What is the impact of reimagining the world historiography with an island bias? Leaving aside both Greenland and Antarctica (mainly because they are not emerged lands), a glimpse on the rest of the world archipelago suggests a broad division into three latitudinal parts with more or less the same longitude span of $120^{\circ}$ (Table 3 and Figure 1): the Americas, Eurafrica with the Middle East as a hinge, and Eastern Asia with its southern insular bridge toward Australia and the Pacific Ocean. They present various overall geographical similarities (Figure 2):

\footnotetext{
${ }^{2}$ More recent work has nuanced this viewpoint, with a more important role envisaged for such invasive species as the rat (Hunt, 2006).
} 


\section{Depraetere}

$\bigcirc$

$\bigcirc$

$\bigcirc$

$\bigcirc$

Bulk of land is located in the northern hemisphere (North America, Europe, Asia);

Peninsulas (South America, Africa) or pavement of islands (Insulindia alias Nusantara and Australia) forming the southern continuation of the northern land masses;

Between these northern and southern land masses, each strip presents narrow isthmus (Panama, Suez), straits (Malacca, Torres), and partially landlocked seas (Mediterranean, Caribbean, China seas); and

Land masses are fringed by network of islands concentrated in specific areas: the Western, Northern and Eastern Canada; Baltic; Norway; the Caribbean.

Table 3: General Figures about the Three Strips of the World Archipelago.

\begin{tabular}{|c|c|c|c|c|}
\hline $\begin{array}{c}\text { Strips, } \\
\text { Name, } \\
\text { Longitude }\end{array}$ & $\begin{array}{l}\text { Western Strip } \\
\text { Americas } \\
169^{\circ} \mathrm{W} \text { to } 35^{\circ} \mathrm{W}\end{array}$ & $\begin{array}{c}\text { Central Strip } \\
\text { Eurafrica } \\
35^{\circ} \mathrm{W} \text { to } 92^{\circ} \mathrm{E}\end{array}$ & $\begin{array}{l}\text { Eastern Strip } \\
\text { 'Asoceania' } \\
92^{\circ} \mathrm{E} \text { to } 169^{\circ} \mathrm{W}\end{array}$ & World \\
\hline Total $\left(\mathrm{km}^{2}\right)$ & $163,860,301$ & $172,276,983$ & $147,680,677$ & $483,817,961$ \\
\hline$\%$ & $33.9 \%$ & $35.6 \%$ & $30.5 \%$ & $100 \%$ \\
\hline Continent $\left(\mathrm{km}^{2}\right)$ & $36,914,881$ & $60,397,377$ & $27,318,894$ & $124,631,152$ \\
\hline$\% /$ total & $22.5 \%$ & $35.1 \%$ & $18.5 \%$ & 25.8 \\
\hline Islands $\left(\mathrm{km}^{2}\right)$ & $2,131,310$ & $1,485,155$ & $4,028,901$ & $7,645,366$ \\
\hline$\% /$ Total & $1.3 \%$ & $0.9 \%$ & $2.7 \%$ & 1.6 \\
\hline$\% /$ Continent & $5.8 \%$ & $2.5 \%$ & $14.7 \%$ & 6,1 \\
\hline Islands (No) & 33,835 islands & 23,938 islands & 23,787 islands & 81,560 \\
\hline $\mathrm{I}>100 \mathrm{~km}^{2}(\mathrm{No})$ & $\begin{array}{c}\text { Including }>100 \mathrm{~km}^{2} \\
503\end{array}$ & $\begin{array}{c}\text { Including }>100 \mathrm{~km}^{2} \\
308\end{array}$ & $\begin{array}{c}\text { Including }>100 \mathrm{~km}^{2} \\
495 \\
\end{array}$ & 1,306 \\
\hline
\end{tabular}

This way of patterning the world's geographical complexities shows didactic similarity with the pedagogic method of the periegesis mentioned earlier. Assume that we have to teach the structure of the world archipelago before considering its various dynamic processes. The most complex geographical configuration is observed in the eastern strip with an elongated mega archipelago encompassing all islands from the North Western Andaman and Nicobar down to the South Eastern French Polynesia and Pitcairn. It covers 20 million $\mathrm{km}^{2}$, and includes 10,000 islands with 3 million $\mathrm{km}^{2}$ of land along an axis of $16,500 \mathrm{~km}$. This 'Andaman-Pitcairn' chain bridges the gap between Indochina and Australia and stretches across the South Pacific towards Rapa Nui and Chile. This geographical entity appears to be more objective than its present division between Asia and Oceania. Moreover, it bears parallels with cultural and biological processes. On the Americas strip, we can observe this type of "nusantarism" for the Great and Lesser Antilles between Florida and Venezuela. In contrast, the Mediterranean on the third Eurafrican strip does not include such typical lines of islands, seemingly trying to connect the sea's northern and southern parts. Such examples provide a more appropriate understanding of our 'world of islands' than the simple remembrance of place locations. 
Figure 1: The Three Latitudinal Strips of the World Archipelago

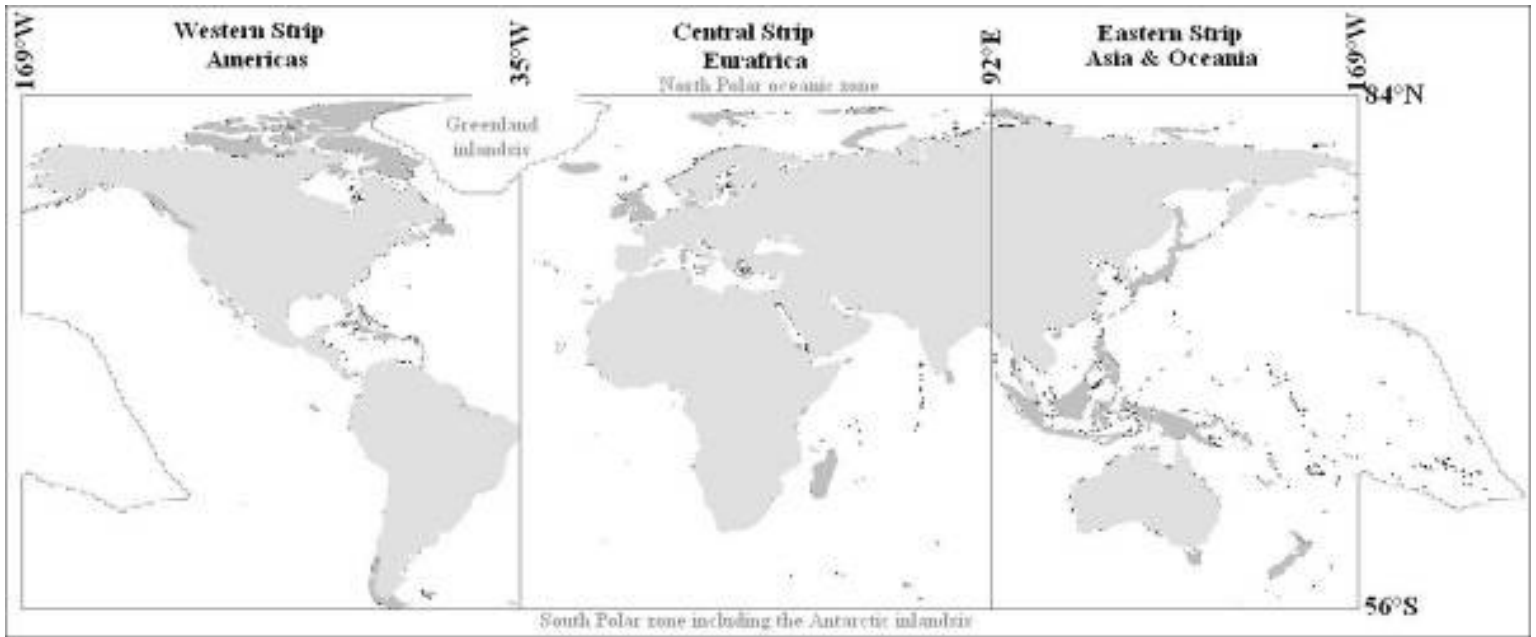

Figure 2: Proportions of Mainlands (Continents) and Islands according to the Latitudes on the Three Strips. Frequencies of Islands are also indicated.

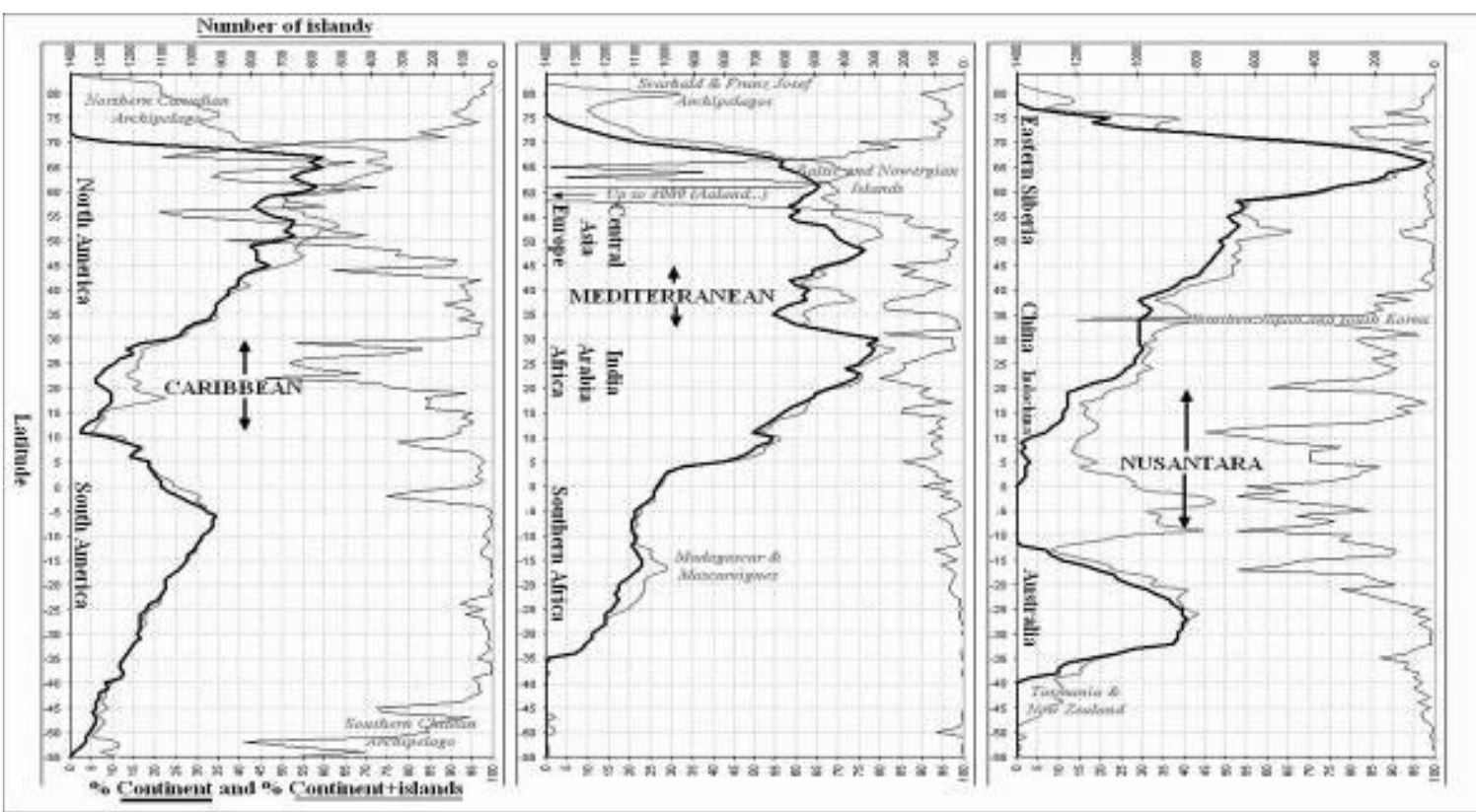

III: Learning from the Nissological View of the World Archipelago, as exemplified by Insular Biodiversity

This mnemonic itinerary leads to a graph-like representation of the world. The rhumb lines on the portolan charts of the $13^{\text {th }}-15^{\text {th }}$ centuries suggest a reticular space, despite the fact that they are already maps, and not sets of itineraries. The systematic use of geographical coordinates, combined with the discovery of both the expanse of the continents (Africa to 


\section{Depraetere}

the South, Asia to the East and the 'New World') and the oceanic vastness at the beginning of the $16^{\text {th }}$ century, gave birth to the grid model with latitude and (later) longitude as we display the world archipelago today (Damisch, 1980). Thus, there was a shift from a reticular to a grid view of global space, leading to a new epistemology of how we conceive and organize the world (Denucé, 1908; Richardson, 2005). Reproducing three-dimensional space on a two-dimensional medium (like a map on a sheet of paper) creates inevitable distortions: these include tacit (and essentially political) assumptions about top and bottom, centres and peripheries, all of which have no real physical portent for a planetary sphere floating in space. Being inherently global, the world archipelago only deserves a spherical, $3-\mathrm{D}$, appreciation and representation ${ }^{3}$; the planar only works on regional or very local scales, where two-dimensional topology is a good enough approximation for physical features.

Nissology - considered as a science of island thinking - links its ultimate expression in the Earth as an island in space, where there is no escape from the imposed geographic limits of our spherical world archipelago. At lower (including continental) scales, insularity always comes with the possibility to externalize its inner limitations or problems. Despite the fractal principle of similarities at different scales observed on the world archipelago (Depraetere, 1991: 127, Depraetere \& Dahl, 2007: 64-66), global viewing reminds us of the limits of trans-scalar reasoning. The general statement "think globally, act locally" implies some nuancing before getting a grip on (local) reality. There is often a failure to grasp 'the big picture', or to seek refuge in a vague ceteris paribus conditionality, in the construction of knowledge (e.g. Ameskamp \& Lamp, 1998; Lamp \& Ameskamp, 1999; Kaci \& Prade, 2007). One major expectation of nissology is to bind together the different but ultimately complementary conceptual approaches of archipelagic and insular structures for the sake of understanding complex processes that work on a large span of scales, such as biodiversity.

The history of evolution in its biogeographic aspect is mainly a question of islands. It is well known that one major source of landscape ecology was the theory of island biogeography (Mac Arthur \& Wilson, 1967). We can go further and say that evolution theory is an offshoot of islophily and periegesis of its main modern promoters, Darwin and Wallace. The insular periplus (San Iago Island in Cape Verde, Saint Paul rock in Brazil, Falklands, Chiloé in Chile and then Galápagos) gave Darwin the opportunity to also observe the physical and geological features of islands (Darwin, 1840). Gohau (1996: 2330-1) reminds us that Darwin was involved in scientific controversy with the geologist Lyell about the nature of island volcanism.

Island patterns webbing the continents, as illustrated by Figure 3, have been important factors in the ongoing processes of biodiversity and endemism, from global to local levels. Such maps of potential island networking based on basic gravitational analogy ${ }^{4}$ hope to

\footnotetext{
${ }^{3}$ This principle, of course, creates its problems in dealing with two dimensional media like paper. And so, unfortunately, various images accompanying this article do not bear out the spherical principle.

${ }^{4}$ The "gravitational" assumption to compute the potential connectivity between two islands is $\operatorname{Ic}=\log \left(\mathrm{A}_{1}\right) \mathrm{x}$ $\log \left(\mathrm{A}_{2}\right) /$ Distance $\left(\mathrm{I}_{1}, \mathrm{X} \mathrm{I}_{2}\right)$, where $\mathrm{A}_{1}$ and $\mathrm{A}_{2}$ are the areas of the two islands $\mathrm{I}_{1}$ and $\mathrm{I}_{2}$. For biodiversity or (is)landscape ecology purposes, using the log of the area leads to more accurate results.
} 
demonstrate that the data, methods and tools required for a detailed modelling of biogeographical processes are now available; these can now contribute to a much better understanding of the biodiversity challenge at any scale. These maps also perform another function: by more clearly representing the dynamic and global connectivity involved in biodiversity, they can bridge conceptual and disciplinary gaps between different stakeholders. We need to remind ourselves that islands are not just local hot spots, but the cornerstones of a global, pan-continental equilibrium.

What about the role of islands in human biodiversity? Cavalli-Sforza's (1997) astounding paper is an attempt to depict the human record at a global scale via the historical framework of cultural evolution through language. At a global scale, there is a remarkable coherence between the genetic population tree and the linguistic tree; it takes the inclusion of the nissological view of the world archipelago to complete this comprehensive understanding of the ecumene. This article has strengthened the role of islands around the world as sites where the patterns and mechanisms of migration and cultural evolution unfold. On their defined and conscribed geography, geneticists cooperate with archaeologists, ethnologists and linguists in this task (e.g. Gibbons, 2001, on the Pacific). Nissologists should be able and keen to contribute to this multi-disciplinary outlook on human history as the history of a world archipelago, and help in the process of modelling this global process (igure 3).

Nevertheless, whereas islands may be at the front line of cultural and biological diversity and occupying the headlines of many sciences, they tend to lose out in representations of physical space. Just like oceans, which are equated with empty space to land loving homo sapiens, islands are either left out or placed at the margins of contemporary world map representations $^{5}$. It is the two main continental masses - EurAsia/Africa and America - that command attention, and centre stage. For example, much of the Pacific Ocean (and all it contains) is typically omitted. "Earth's Empty Quarter", as Ward (1989) called it. Nissology calls us to attention about the smaller, and neglected, bits of the world archipelago. By privileging the small, marginal and insular, the emphasis on the world archipelago seeks to reverse political polarity. A nissological representation would celebrate island issues as a main element of the world pattern and system, and not as a marginal consideration of (at best) local relevance. Nissology should help to make islands less incidental in how they are appraised by those more acquainted and accustomed to continental thinking.

\section{Nissology as a Hard Science}

"What we call a science constitutes in fact a large number of micro sciences or theories. As a consequence, what we call a science had better be called a macro science" (Tinbergen, 1989: 3).

\footnotetext{
5 So, by way of example, the word "island" is neither in the index nor in the text of many books which purport to be commentaries on global and international issues (e.g. Rosen \& Jones, 1980). The global/world maps on the cover of such books do not even have major islands included. A much more recent 'international' book - Punnett (2005) - even omits Greenland from the map on its book cover.
} 


\section{Depraetere}

Figure 3: A Web-Like Structure of Island Networks flanking the Continent and crisscrossing the Oceans. Based on Graphic Rendition of Island Nodes representing their Potential Biodiversity according to their Area (Area/Species Relationship).

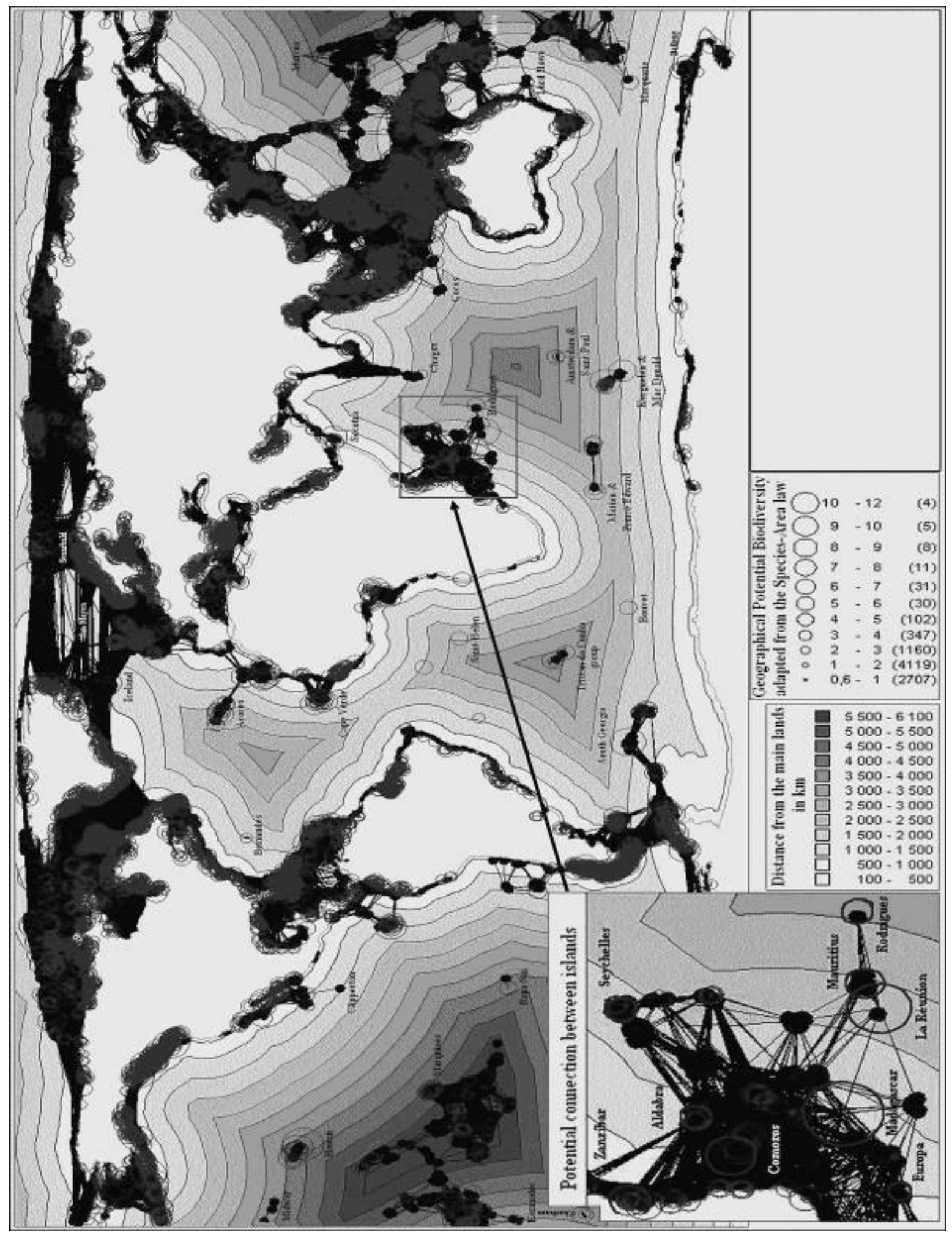


A key question relating to the division of knowledge and the definition of macro versus micro sciences has been raised by various authors. Several "object-oriented" elementary sciences within geography focussing on specific features of the Earth have been identified: potamology for the study of rivers, orology for the study of mountains, karstology, glaciology ... even eremology as the science of deserts. As far as possible, we would like to avoid getting involved in a sterile epistemological debate as to whether or not it makes sense to have an 'object-oriented' science dedicated to the study of islands. And yet, how would such a phenomenological approach contribute to the multi-dimensional challenge of sustainable development?

Given the strong geographical presence of islands - real and mythical - in human history, the absence of a long pedigree of 'island studies' should be surprising. When contrasted with other object-oriented sciences, three arguments in particular are suggested as explanations for this absence of nissological scholarship:

- Despite all the literature about the definition of an island, the 'island object' remains a rather controversial notion (Royle, 2007);

- The 'island phenomenon' does not apply only to islands per se but to any area offering a drastic contrast with its surroundings;

- The overbearing presence of islands in human thoughts, perceptions or even life (Brigand, 2006).

The first point above can lead to endless debate, with no general definition coming out of what is an island... and what is not! This is why it is proposed that nissology should encompass all emerged lands at any scale (Depraetere \& Dahl, 2007). A reminder to the fractal nature of objects should be enough to alert us to the key difference between the world archipelago and, say, the Scilly Isles at the tip of Penzance peninsula in Britain, which is one of scale. With such a lens, one can envisage the Americas as a large island beside the Old World, and the main island of St Mary's in the Scillies as the mainland, a small continent.

The second point stresses that 'the island' is a generic term that goes far beyond the case of land surrounded by water. As Carlquist (1965) reminds us, many geographical patterns are island-like; in combination, they behave just like archipelagos. These features include: the aptly named inselbergs ${ }^{6}$ emerging from the vast flatness of tropical peneplains (Barthlott \& Porembski, 2000) (Figure 4 and Photo 1); the guyots (or seamounts) spotting the abyssal plains of the oceans, especially in the North-West Pacific (Figure 5); patchy remnants of forest within cultivated regions; patches of taiga within tundra; and the numerous lakes in periglacial zones. Lakes should be of peculiar interest because they are obverse islands: bodies of water surrounded by land. Such "anti-islands" show significant statistical similarity with true islands (Figure 6a and Figure 6b), as suggested by an exhaustive survey of lakes on Madagascar (Figure 7).

\footnotetext{
${ }^{6}$ From the German insel for island and berg for mountain, a term coined by Bornhardt (1900).
} 


\section{Depraetere}

Figure 4: An Archipelago of Inselbergs as Dry Islands within the Meshes of Rivers and Valleys as Wet Zones over the West-African Peneplain (Benin).

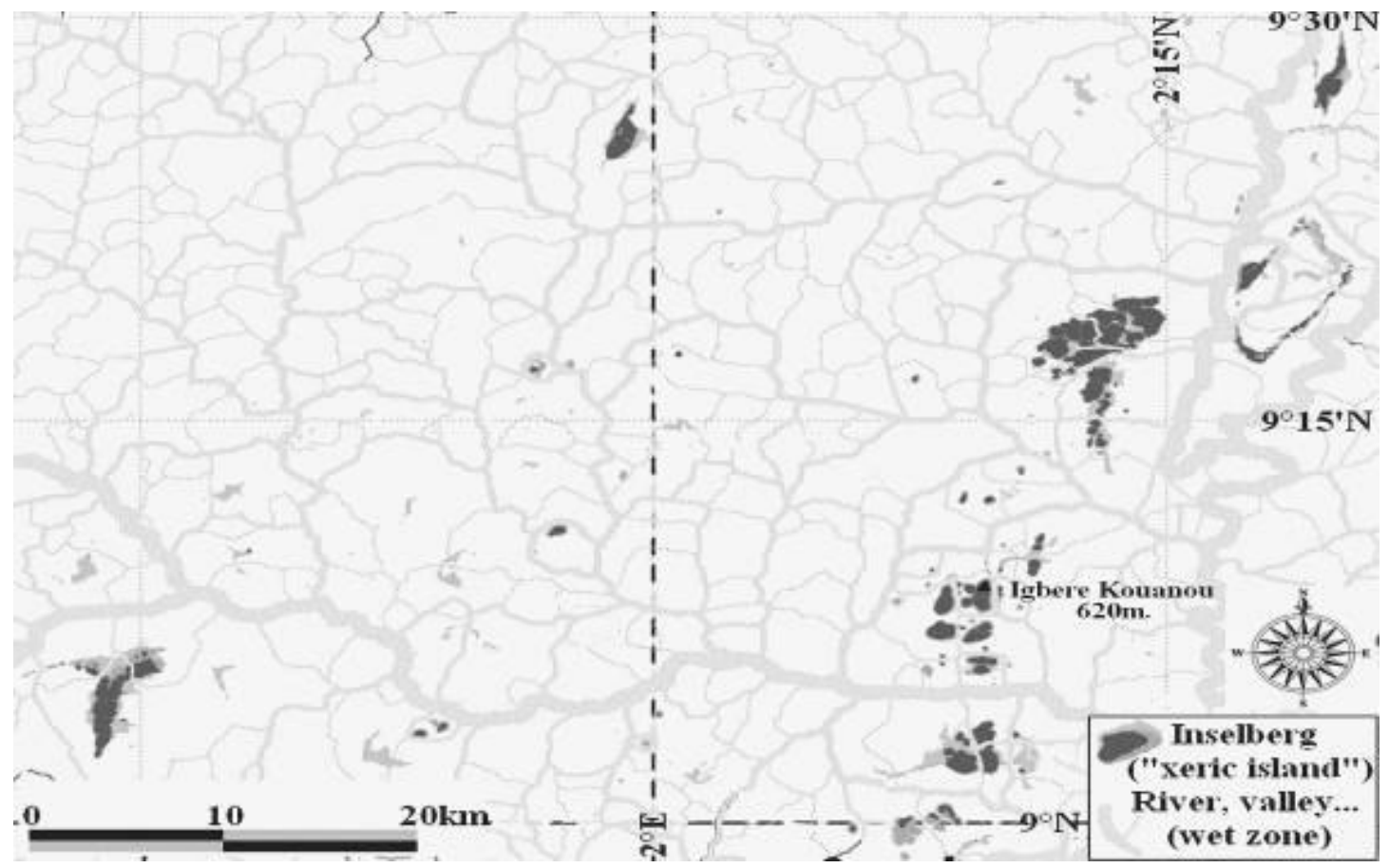

Photo 1: Panorama of the Igbere Kouanou Inselberg Group viewed from the North. It illustrates an 'archipelago like' group of inselbergs indenting the flat horizon of an 'ocean like', vast savannah. Foreground shows an inselberg with trace of runoff (Photo: $C$. Depraetere, July 2002).

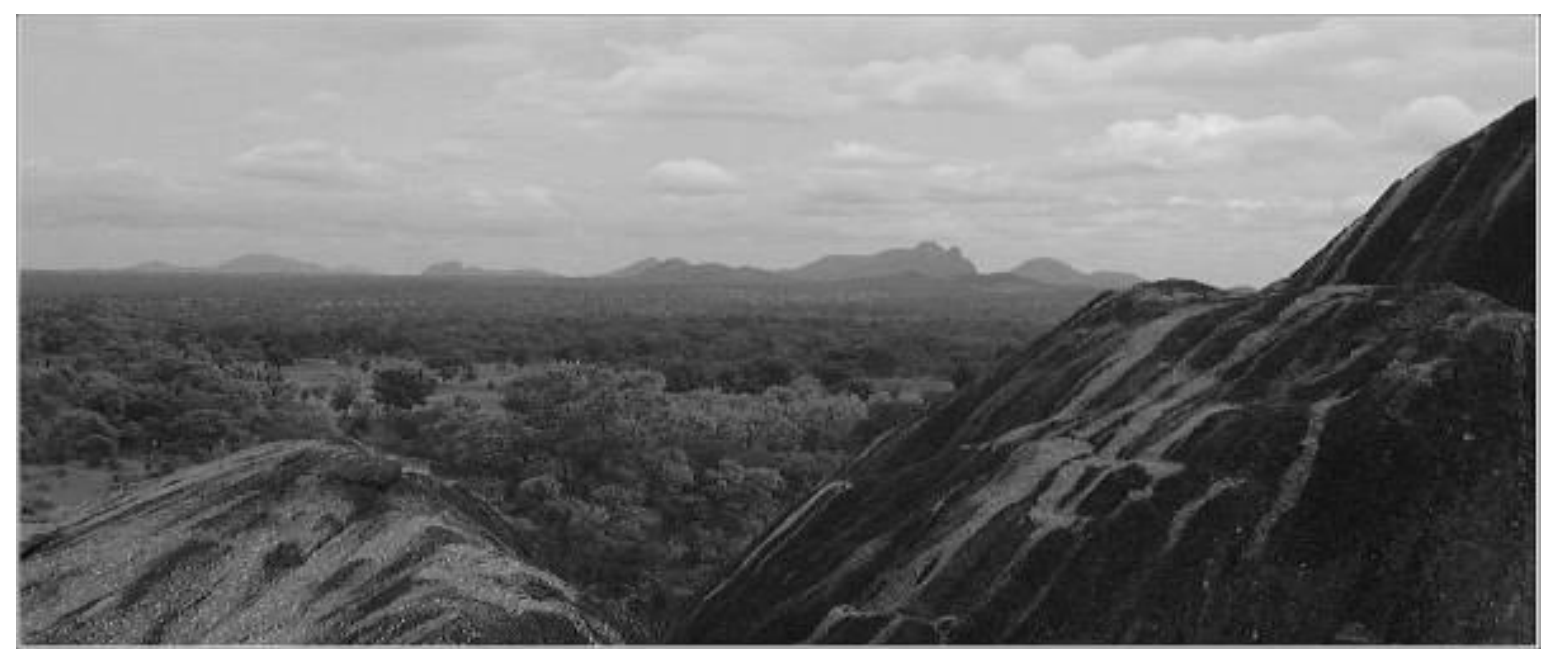

Finally, in terms of landscape ecology, human encroachments on large ecosystems create smaller units functioning as pseudo-islands: 
"Island biogeography is no longer an offshore enterprise. It has come to the mainlands. It's everywhere. The problem of habitat fragmentation, and the plants and animals left marooned within the various fragments under circumstances that are untenable for the long term, has begun showing up all over the land surface of the planet" Quammen (1996: 549).

Due to the breaking apart of continental biotopes), giving birth to puzzle-like archipelagic natural or sub-natural habitats (see Figure 7, for an example from The Philippines), the same author stated that "the world is in pieces". The concepts of island biogeography are now largely used to describe even continental biomes because:

"[A]11 over the planet, the distributional maps of imperilled species are patchy ... the mainlands are going, going, gone; the world is in pieces; and reality conforms to a new model" (Quammen, 1996: 602).

\section{Figure 5: Guyots or Seamounts in the North-Western Pacific.}

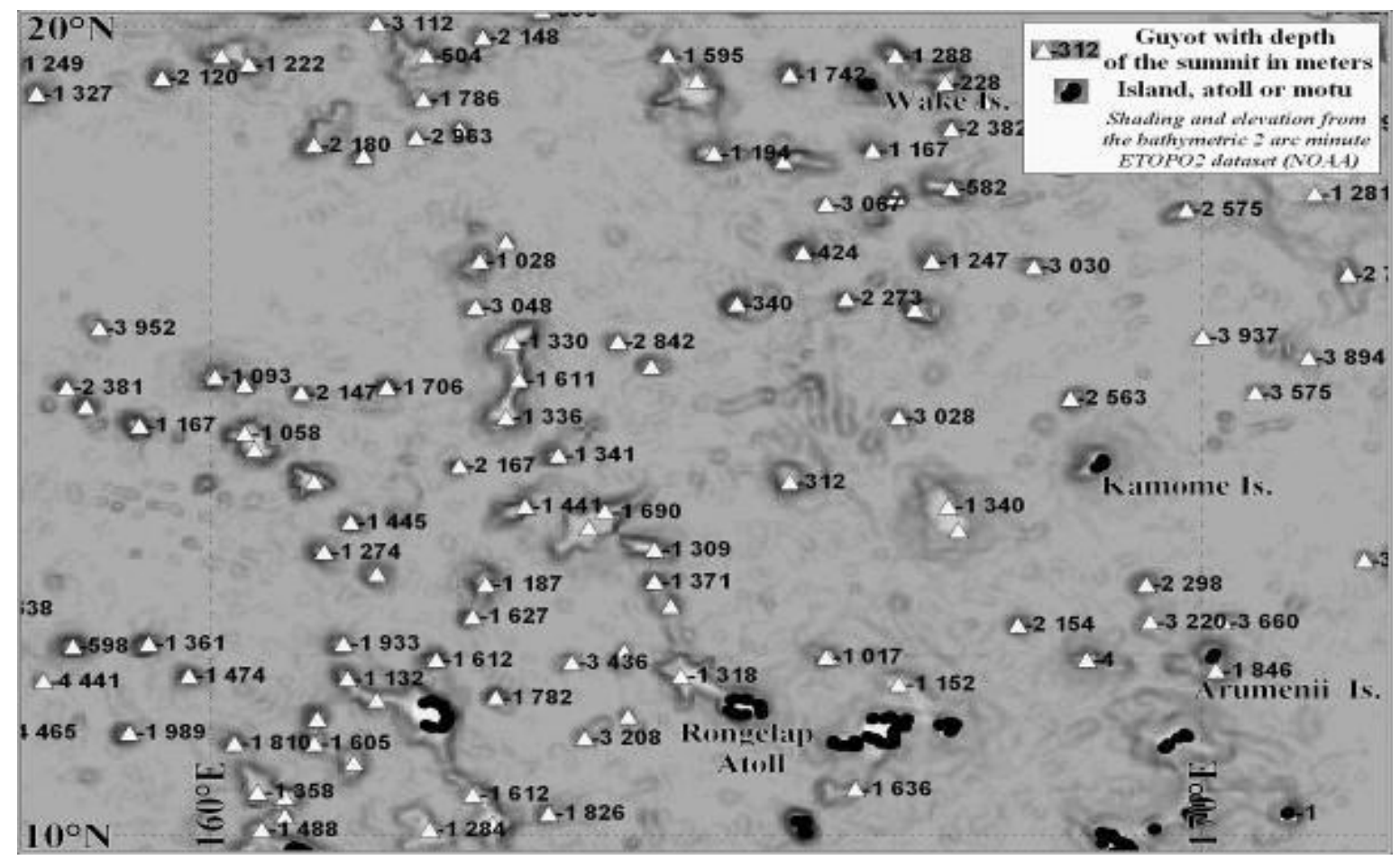

This notion of the fragmentation of the natural continental biotope can also be extended to the sphere of human cultures. To illustrate this gradual shift from geology, biology up to ethnology, we may suggest to create the term "ethnotope" that can be deployed as the counterpart to geotope, ecotope and biotope: an ethnotope is an area of alike cultural

\footnotetext{
7 The term "ethnotope" is used by Van Wesemael (2001: 47): "In the course of the $19^{\text {th }}$ century, material objects and explications were gradually replaced by context oriented and habitat presentations in which objects were displaced in their self-evident or narrative coherence of their 'biotope', 'sociotope', or 'ethnotope'."
} 


\section{Depraetere}

conditions rooted in a specific land for a human community sharing related history, languages, lifestyles and values. The fragmentation of continental ethnotopes bears a certain affinity with the previous comment about "the world in pieces"? Many cultures under threat strive to survive on/as "vanishing archipelagos" and "sinking and shrinking islands". One poignant and emblematic example - and there are many - is the break up, dispersal (and islandization) of the native American Indian territories, lifestyles and cultures in the Western USA during the late $19^{\text {th }}$ century (Figure 9). After several decades of war and systematic infringements, the outcome at the beginning of the $20^{\text {th }}$ century is that of an archipelago-like structure of Indians ethnotopes representing less than $5 \%$ of their original territory and population.

Figure 6a: Plotting of $\operatorname{LogF}$ versus LogS for Islands $>0.1 \mathbf{~ k m}^{2}$ for the entire World Archipelago (Depraetere \& Dahl, 2007). Figure 6b: Plotting of LogF versus LogS for Lakes $>0.26$ km$^{2}$ for Madagascar (Ferry, Depraetere \& Robison, 1995).
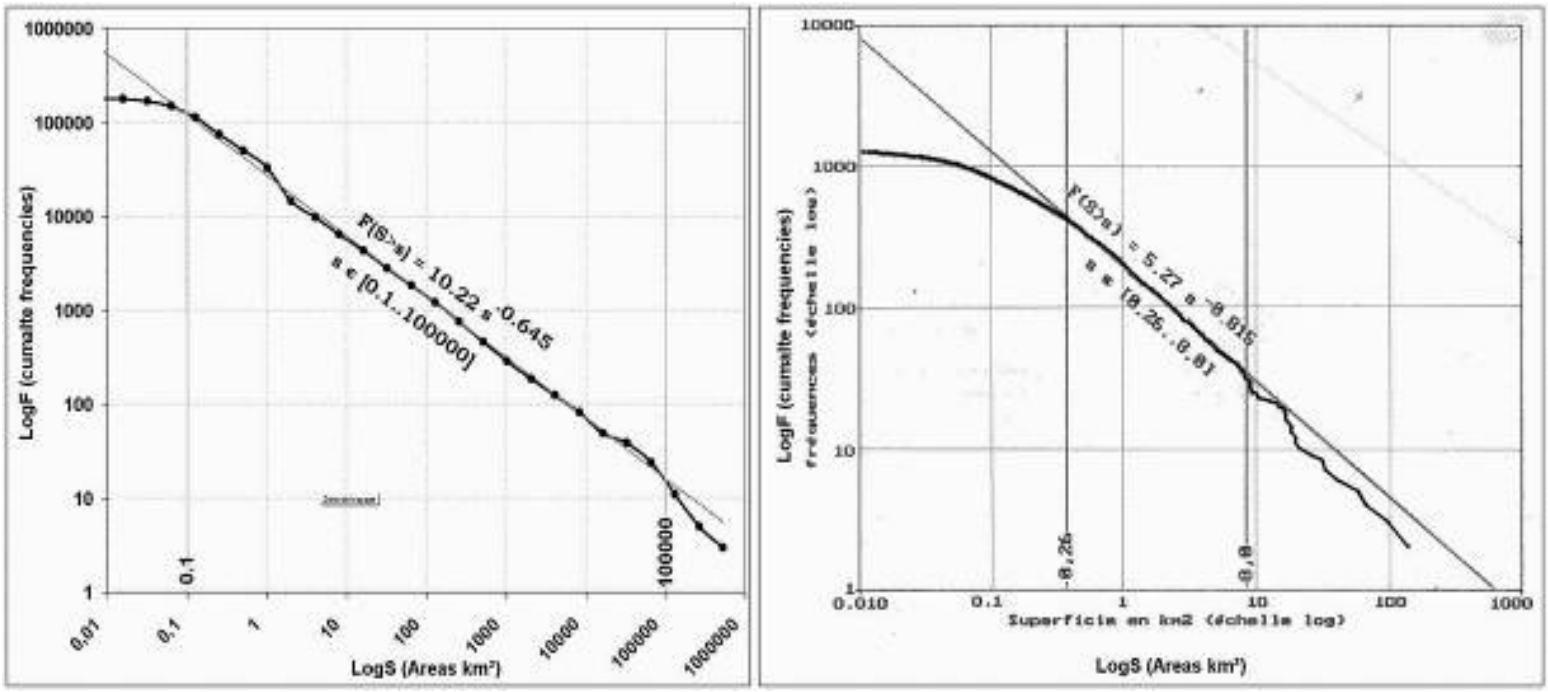

The island phenomenon and its geographical cognates thus recur regularly and frequently throughout the Earth. Nissology can allege some sort of foreknowledge to model the consequence of such widespread structures and processes. We can even go further and state a sort of anti-tautology that... islands are not only islands.

The third point is probably the most intricate because it deals with the subjective perception and interpretation of the island phenomenon. The extreme position here is to argue that there is no such thing as an island, but only figurative and metaphorical representations and mental schema. Natural scientists will have serious misgivings about such statements (e.g. Baldacchino, 2008). Admittedly, nissology has to demonstrate its ability to illuminate our understanding of island structures at any scale, as well as to propose general laws that concern the processes and phenomena observed on such islands. And yet, should we leave out what Jorgen Rasmussen in a recent 'island studies blog, 8 referred to as "the nissosophical approach" just because it does not frame with the

\footnotetext{
${ }^{8}$ Visit 'island studies blogs' at: http://www.islandstudies.ca/blog.html.
} 
proposition that nissology is a hard science where physical and social scientists might share common enlightenment? Instead, the foray into representation and metaphor is an opportunity and not a burden for nissology. There is scope to transform even the nissosophical project into an appreciation of, and for, the world archipelago It makes perfect sense to have (at least) two diverging, but hopefully complementary, approaches within a diagonal science. Nissology has the potential to be all-embracing, combining both the hard and soft approaches to the island phenomenon. Berque (1993: 194) provides good advice, alerting us to the need and urgency to look, and strive, for commonalities:

"We ought to stop opposing the subjective approach [of islandness] ... to the scientific - objective approach [of islands] ... At the same time, we had better stop opposing global to local, or even morality or art to science: all these are bound together. There is a need to overcome such oppositions: in order to build a modern, sustainable world."9

Figure 7: Survey of the Lakes of Madagascar. Lakes function like Islands, with Major Water Divides as Frontiers for Lacustrine Species.

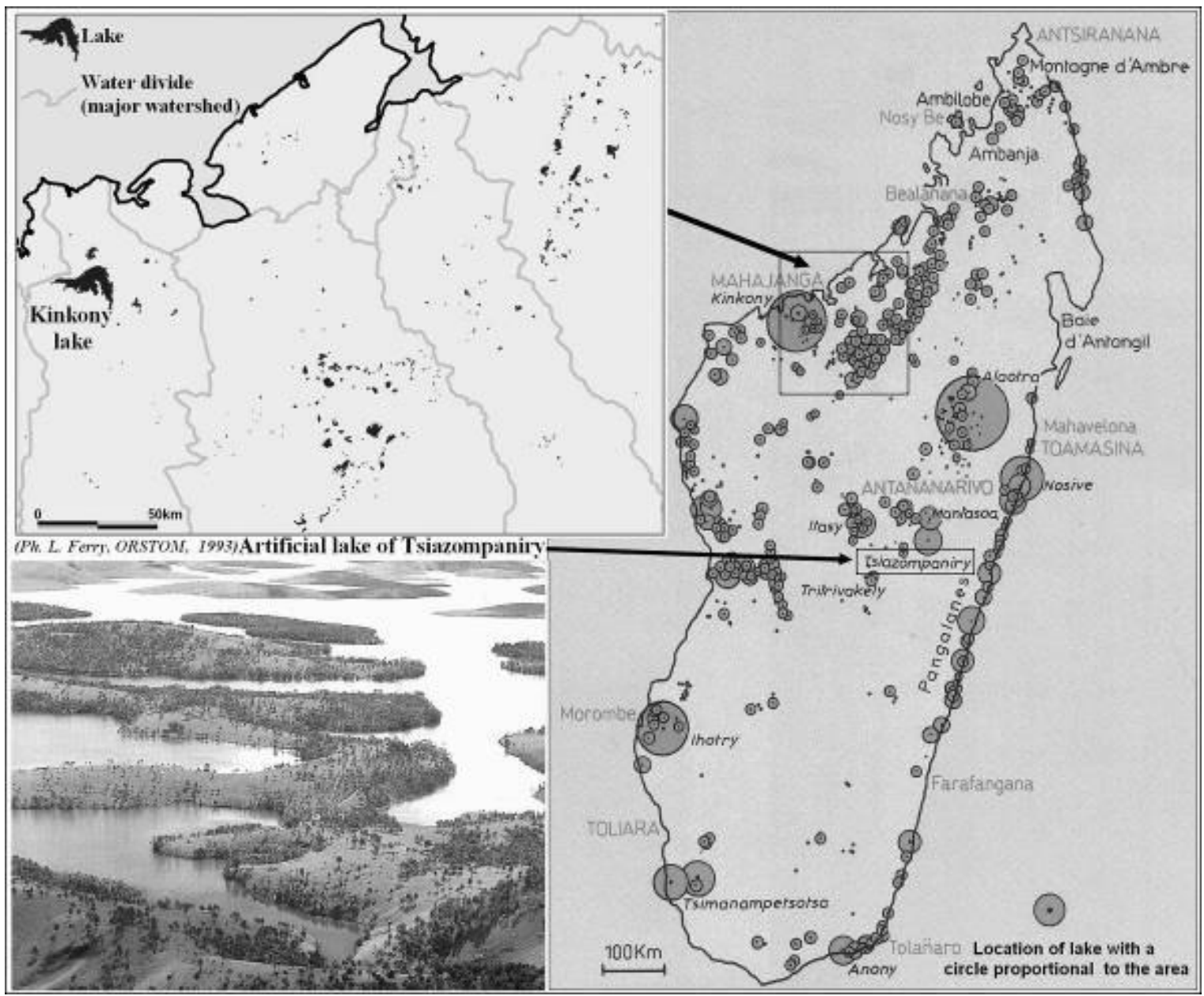

\footnotetext{
${ }^{9}$ Translated and adapted from the French original by the author.
} 


\section{Depraetere}

Figure 8: Example of fragmentation of former continuous forested biotopes covering the islands of Cebu, Bohol Camiguin and Siquijor, Philippines Archipelago. The land cover comes from a pre-classified global land cover map at $300 \mathrm{~m}$ resolution, using a MERIS sensor on board the ENVISAT satellite: http://postel.mediasfrance.org.

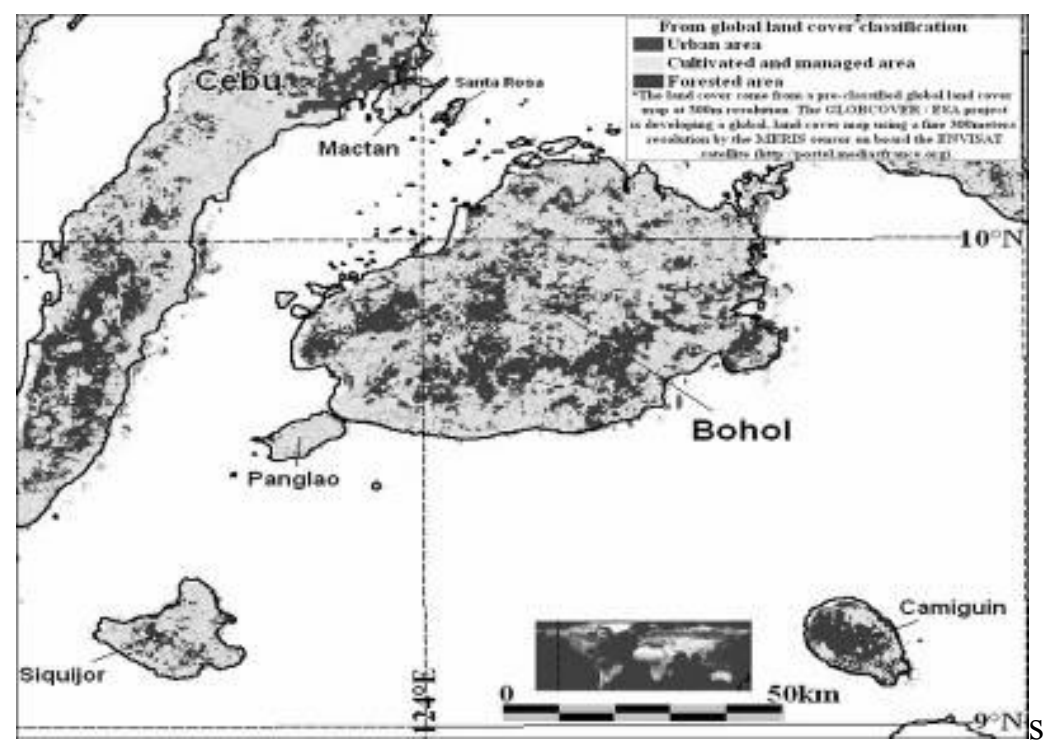

Figure 9: Fragmentation of Lands and Peoples in Western USA with "Island-like" Ethnotopes of Amerindians after the Indian Wars (1860-1890 and today).

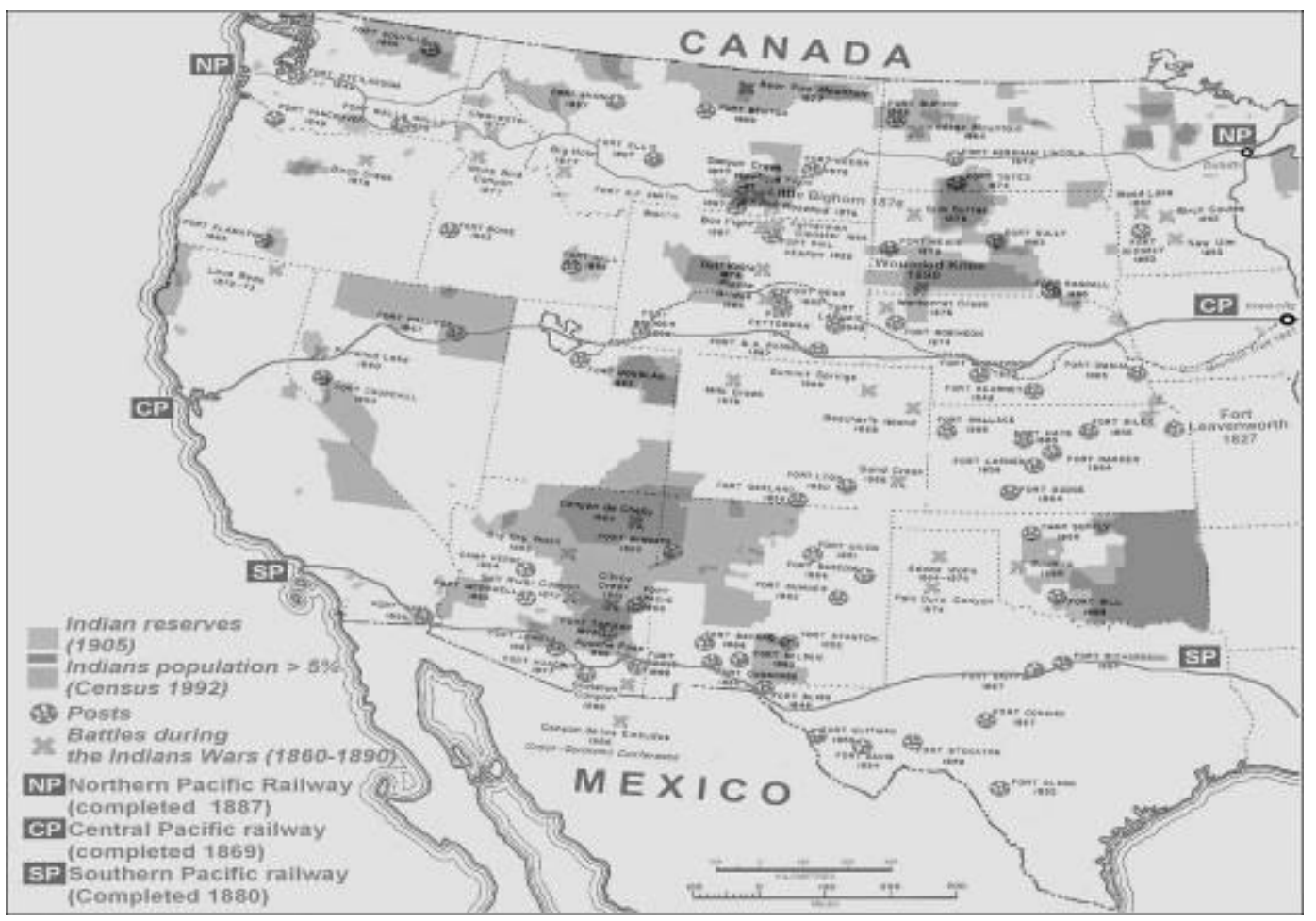




\section{Conclusion}

'Island Studies' has always been a special breed of science, being inter and multidisciplinary but also multi-dimensional, as evidenced by the work and lives of such anthropologists as Joël Bonnemaison (1986; 1994) or Greg Dening (2004). Both were scientific beachcombers in the normative sense; but, for them, islands, islanders and islandness were also mirrors by which they could understand themselves better and thus embrace the World and the ecumene. Meanwhile, and in spite of a number of seminal contributions to knowledge across disciplines - like those by Darwin, Wallace, Hooker, Malinowski and Simberloff \& Wilson - one still comes across claims that 'island studies' "lacks a home-grown theory" (Teaiwa, 2001: 346, as applied to Pacific Studies). Various authors have stressed the need for a unifying theory or concept that could help to federate the "islophile" (Hay, 2006: 20). There is still quite a long way to go before 'island studies' can debunk "continental thinking”, as emphasized by Grant McCall (1994, 1996).

Meanwhile, island scholars must respond to the inherent archipelago-like connectedness of their subject matter. In spite of their simplistic rendering, there is a series of binary principles that strike me as lying at the core of island studies debates for the medium term: these go beyond the usual antinomies of home and away, openness and closure, paradise and prison. They involve materiality and metaphor, continentalism versus archipelagicity, insider versus outsider, apolitical versus subaltern island studies. One hopes that there is enough interest and momentum to take this debate forward.

For now, the world archipelago beckons. A pluri-disciplinary paradigm is needed, one which acknowledges islands as the embodiment of the complexity of today's challenges. There is a growing realization, and resignation, that islands will be one of the major playgrounds for key $21^{\text {st }}$ century issues, such as biological and cultural diversity, and not just in the narrow manner of MacArthur \& Wilson (1967). Islands deserve nissology, even if this science of islandness remains an epistemic challenge. The global island network matters: specific islands are not only important because they present small, manageable, laboratory scale settings. There is, one hopes, a sort of 'scientific millenarism' in the air.

\section{References}

Ameskamp, M. \& Lamp, J. (1998) 'Three-dimensional soil prediction: Fuzzy rules and a GIS' in H.J. Heineke, W. Eckelmann, A.J. Thomasson, R.J.A. Jones, L. Montanarella \& B. Buckley (eds.) Land Information Systems: Developments for Planning the Sustainable Use of Land Resources, Luxembourg, European Commission, pp. 243-250.

Baldacchino, G. (2008) 'Studying Islands: On Whose Terms? Some Epistemological and Methodological Challenges to the Pursuit of Island Studies', Island Studies Journal, Vol. 3, No. 1, pp. 37-56.

Barthlott, W. \& Porembski, S. (2000) 'Why Study Inselbergs?' in S. Porembski \& W. Barthlott (eds.) Inselbergs: Biotic Diversity of Isolated Rock Outcrops in Tropical and Temperate Regions, Ecological Studies No. 146, Berlin, Springler-Verlag, pp.1-6. 


\section{Depraetere}

Berque, A. (1993) 'Environnement Planétaire et Paysage', Recherche et Débats Interdisciplinaires : Natures, Sciences, Sociétés, Vol. 1, No. 3, Association NSS Dialogue Dunod, Paris, pp. 194-199.

Bonnemaison, J. (1986) La Dernière Île, Paris, Arka/Orstom. (Oceania, Vol. 60, No. 1, 1989).

Bonnemaison, J. (1994) The Tree and the Canoe: History and Ethnogeography of Tanna, translated and adapted by J. Pénot-Demetry, Honolulu HI, University of Hawaii Press.

Bornhardt, W. (1900) Zur Oberflachengestaltung und Geologie Deutsch-Ostafrikas, Berlin, Dietrich Reimer.

Brigand, L. (2006) 'Que serais-je sans elles? Relation d'un Voyage d'un Quart de Siècle d'Île en Île' in J.-P. Castelain (ed.) Îles Réelles, Illes Rêvées, Ethnologie Française No. 2006/3, Paris, pp. 475-483.

Carlquist, S. (1965) Island Life: A Natural History of the Islands of the World. Garden City NY, American Museum of Natural History, The Natural History Press.

Cavalli-Sforza, L.L. (1997) 'Genes, Peoples and Languages', Proceedings of the National Academy of Sciences (USA), Vol. 94, No. 15, pp. 7719-7724.

Dahl, A.L. (1996) The Eco Principle: Ecology and Economics in Symbiosis, London, Zed.

Darwin, C.R. (1840) 'On the Connection of Certain Volcanic Phenomena in South America, and the Formation of Mountain Chains and Volcanoes as the Effect of the Same Powers by which Continents are elevated', Transactions of the Geological Society, Series 2, Vol. 5, No. 3, pp. 601-631.

Depraetere, C. (1991) 'Le Phénomène Insulaire à l'Échelle du Globe: Tailles, Hierarchies et Formes des Îles Océanes', L'Espace Géographique, Montpellier, GIP Elisé Reclus, Vol. 2, pp.126-134.

Depraetere, C. \& Dahl, A.L. (2007) 'Island Locations and Classifications' in G. Baldacchino (ed.) A World of Islands. An Island Studies Reader, Malta \& Canada, Agenda Academic and Institute of Island Studies, pp. 57-105..

Depraetere, C. \& David, G. (2008) 'Préambule et Postface Actuels à une "Déclaration d'Intention pour un Projet de Création d'un Groupe ILES", écrite en 198'. A la mémoire de Joël Bonnemaison (1940-1997)', in L'Archipel des Lettres: La Revue des Littératures Insulaires, Semestriel, No. 2, May, p. 89-105.

Diamond, J. (1995) 'Easter's End', Discover: Science, Technology and the Future, No. 8, August, pp. 62-69. 
Damisch, H. (1980) 'La Grille comme Volonté et comme Représentation' in Cartes et Figures de la Terre, Paris, Centre George Pompidou, pp. 30-40.

Dening, G. (2004) Voyaging Across Times, Cultures, and Self, Philadelphia, University of Pennsylvania Press.

Denucé, J. (1908) Les Origines de la Cartographie Portugaise et les Cartes des Reinel, Belgium, Gand.

Dirlik, A. (2005) 'Performing the World: Reality and Representation in the Making of World Histories', Journal of World History, Vol. 16, No. 4, pp. 391-410.

Ferry L., Depraetere C. \& Robison L. (1995) 'Premiers Résultats d'une Étude Générale sur les Lacs Malgaches', Journées ORSTOM à l'Académie Malgache: 50ème Anniversaire de l'ORSTOM, Bulletin de l'Académie Nationale Malgache, pp. 30-46.

Gibbons, A. (2001) 'Peopling of the Pacific', Science, Vol. 291, No. 5509, pp. 1735-1737.

Gohau, G. (1996) 'Iles Volcaniques' in P. Tort (ed.) Dictionnaire du Darwinisme et de l'Evolution, 3 volumes, Paris, Presse Universitaire de France, pp. 2330-2331.

Gowdy, J.M. \& McDaniel, C.N. (1999) 'The Physical Destruction of Nauru: An Example of Weak Sustainability’, Land Economics, Vol. 75, No. 2, pp. 333-338.

Hay, P. (2006) 'A Phenomenology of Islands', Island Studies Journal, Vol. 1, No. 1, pp. $19-42$.

Hunt, T. (2006) Rethinking the Fall of Easter Island: New Evidence points to an Alternative Explanation for a Civilization's Collapse', American Scientist, Vol. 94, No. 5, pp. 412-419.

Kaci, S. \& Prade, H. (2007) 'Relaxing ceteris paribus Preferences with Partially Ordered Priorities' in K. Mellouli (ed.) European Conference on Symbolic \& Quantitative Approaches to Reasoning with Uncertainty, Hammamet, Tunisia, Springer, pp. 660-671.

Kluckhohn, C. (1970) Mirror for Man: A Survey of Human Behaviour and Social Attitudes, Greenwich CT, McGraw Hill.

Lamp, J. \& Ameskamp, M. (1999) Definition and Use of Functional Soil Horizons as Keys in Spatial Land Information Systems, European Soil Bureau, Report No. 4, pp. 279-292.

MacArthur, R.H. \& Wilson, E.O. (1967) The Theory of Island Biogeography, Monographs in Population Biology No. 1, Princeton NJ, Princeton University Press.

McCall, G. (1994) 'Nissology: The Study of Islands', Journal of the Pacific Society, Vol. 17, Nos. 2-3, pp. 1-14. 


\section{Depraetere}

McCall, G. (1996) 'Clear Confusion in a Disembedded World: The Case for Nissology', Geographische Zeitschrift, Vol. 84, No. 2, pp. 74-85.

Orr, I. (2007) The Foreign Affairs Committee Inquiry into the Role of FCO and the Overseas Territories, Memorandum submitted by BioDiplomacy, www.biodiplomacy.org.

Ponting, C. (1993) A Green History of the World. The Environment and the Collapse of Great Civilizations, New York, Penguin.

Punnett, B.J. (2005) Experiencing International Business and Management: Exercises, Projects and Cases, Armonk NY, M. E. Sharpe.

Quammen, D. (1996) The Song of the Dodo: Island Biogeography in an Age of Extinctions, New York, Scribner.

Richardson, B.W. (2005) Longitude and Empire: How Captian Cook's Voyages Changed the World, Vancouver, Canada, UBC Press.

Royle, S. A. (2007) 'Definitions \& Typologies' in G. Baldacchino (ed.) A World of Islands. An Island Studies Reader, Malta \& Canada, Agenda Academic and Institute of Island Studies, pp. 33-56.

Rosen, S.J. \& Jones, W.S. (1980) The Logic of International Relations, Cambridge MA, Winthrop Publishers.

Teaiwa, T. (2001) 'L(o)osing the Edge', The Contemporary Pacific, Vol. 13, No. 2, pp. 343-365.

Tinbergen, J. (1989) 'The Impact of the Forecasting Capacity of One Science on That of Other Sciences”, International Journal of Forecasting, Vol. 5, No. 1, pp. 3-5.

UNESCO (2008) Socio-Cultural Dimensions of Island Development, http://portal.unesco.org/en/ev.php-

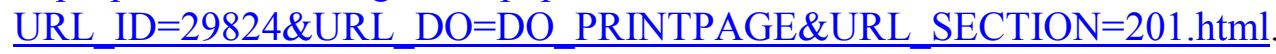

Van Wesemael, P. (2001) Architecture of Instruction and Delight: A Socio-Historical Analysis of World Exhibitions as a Didactic Phenomenon: 1798 - 1851 - 1970, Rotterdam, 010 Publishers.

Ward, R. G. (1989) 'Earth's Empty Quarter? The Pacific Islands in a Pacific Century', The Geographical Journal, Vol. 155, No. 2, pp. 235-246.

Wurm, S.A. (2001) Atlas of the World's Languages in Danger of Disappearing, Memory of Peoples Series, Paris, UNESCO Publishing. 